\title{
Making ESPON knowledge more tangible for detecting regional potentials and challenges: five territorial approaches ${ }^{1}$
}

\author{
Lukas Smas a, Peter Schmitt a, b \\ a Nordregio - Nordic Centre for Spatial Development \\ Holmamiralens Väg 10, Skeppsholmen, Stockholm, Sweden \\ lukas.smas@nordregio.se,peter.schmitt@nordregio.se \\ b Stockholm University, Department of Human Geography \\ SE-106 91 Stockholm, Sweden,
}

\begin{abstract}
The ESPON DeTeC (Detecting Territorial Potential and Challenges) project has developed five territorial approaches that can support regional stakeholders in revealing and detecting challenges and potential within a wider territorial context from a European perspective. The objective of this article is to present these approaches, which can be used to make ESPON knowledge more tangible and which can help in navigating through the inherent tensions, associated with the policy concept of territorial cohesion. In doing so, the article provides at first a brief introduction to the concept of territorial cohesion, a presentation and discussion of the territorial approaches with a particular focus on how they address exogenous challenges and endogenous potentials, conceptualize regional territories within relational spaces, and finally, how they direct attention towards territorial governance and the fluidity of scales and places. It is a practice oriented article that in conclusion discusses how territorial approaches can provide guidance for strategic local and regional policy making and how they help to open up new perspectives in local and regional development through the application of ESPON knowledge.
\end{abstract}

Keywords: territorial cohesion, territorial approaches, ESPON.

\section{Introduction}

In a Europe of regions it is essential for regional stakeholders to identify regional potential and challenges in order to develop sound development strategies and to improve the region's adaptive capacity

\footnotetext{
1 This paper has been developed under the Scientific Platform project Detecting Territorial Potential and Challenges led by Nordregio, Sweden. It has been financed by the ESPON 2013 Programme and its financial support is gratefully acknowledged. Texts, maps and conclusions stemming from research projects under the ESPON programme presented in this paper do not necessarily reflect the opinions of the ESPON Monitoring Committee. (C) ESPON, 2014.
} 
to be responsive against changing contexts. The ESPON DeTeC (Detecting Territorial Potential and Challenges) project has developed five territorial approaches that can support a region to reveal and detect its challenges and potential within its wider territorial context from a European perspective. The idea of territorial approaches comes from a demand for integrating a territorial perspective into European policymaking as well as a European perspective in regional policymaking. However, there are inherent potential tensions within EU's drive towards territorial cohesion with regard to exploiting territorial diversity and at the same time enhancing the regional competitiveness and promoting harmonized and balanced territorial development. These policy tensions, which are related to processes of regionalisation and globalisation, and to issues of relational and/or territorial conceptualisations of space, are reflected in the five territorial approaches that have been developed within the ESPON $\mathrm{DeTeC}$ project. These territorial approaches are thus designed to identify exogenous challenges and endogenous potential as well as to consider regional territories as relational spaces. In this vein it seems to be crucial that territorial governance focus on the potentialities of regions but simultaneously recognise them in a relational perspective (and not solely as fixed territories) in order to detect their territorial potential and challenges.

From its start in 2002, ESPON (the European Observation Network for Territorial Development and Cohesion) has been conceived of as a knowledge base to support transnational spatial policymaking. Since then, the ESPON programme has produced an extensive evidence on territorial dynamics and driving factors summarised in (or expressed by) a number of scientific reports, targeted analyses, thematic maps and spatial indicators. The first ESPON programme ran from 2002 to 2006, and, as Duehr et al. (2010:247) put it, "aimed at providing detailed spatial information for the EU territory and to set up a decentralised network of spatial research institutes across Europe". The content areas of the ESPON 2006 projects were closely aligned to the thematic scope stipulated by the European Spatial Development Perspective (CEC 1999), including topics such as the role of cities in regional development, urban-rural relations, polycentricity and accessibility, about which the ESPON 2006 programme has provided some robust findings.

The second phase of ESPON, the so-called ESPON 2013 programme, has been aligned to the Lisbon and Gothenburg strategy as well as the ongoing discussions around the concept of territorial cohesion (see next section). Within the ESPON 2013 programme different so-called priority areas were defined that shall contribute to the co-production of European knowledge base on territorial development and cohesion. As a "Scientific Platform and Tools" project the ESPON DeTeC project has strived to meet the demand for analytical methods and approaches and to support local and regional practitioners and policymakers in their search for ways to identify territorial potential by applying, in particular, a European perspective. The objective of the ESPON DeTeC project has been to provide practical guidance on how to utilize ESPON knowledge to identify territorial potential and to provide concrete and illustrative examples of "good" practices. The main output of the project is an interactive handbook providing practical guidance and concrete examples to practitioners and policy makers in an easy and understandable way.

The objective of this article is to present and describe the territorial approaches developed within the ESPON DeTeC project and how they can be used to make ESPON knowledge more tangible for detecting territorial potential and challenges and which can help in navigating through the inherent tensions, associated with the policy concept of territorial cohesion. The next section provides a brief introduction to the concept of territorial cohesion, its internal tensions and different interpretations. In the following sections the territorial approaches, developed within the DeTeC project, are presented with a particular focus on how they address exogenous challenges and endogenous potential, con- 
ceptualize regional territories within relational spaces, and finally, how they direct attention towards territorial governance and the fluidity of scales and places. In conclusion, the article discusses the policy relevance of the territorial approaches and the importance of recognising the different tensions within territorial development and the concept of territorial cohesion.

\section{Navigating the tensions of territorial cohesion}

As mentioned above, the ESPON 2013 programme has been closely aligned to the policy concept of territorial cohesion. It was introduced as a third dimension in the EU cohesion policy, alongside economic and social cohesion, within the Treaty of Lisbon adopted in 2007. According to Scott (2009:649), cohesion in general is "a principle of promoting economic prosperity and social justice within the European Union (EU) in order to avoid socioeconomic fragmentation and greater regional disparities". There is, however, no EU-wide consensus with regards to its meanings and principles in different territorial contexts, and, perhaps most importantly, in the world of policymaking, concerning robust and at best quantifiable indicators for measuring the impacts of policies of territorial cohesion (see for instance the discussion in Planning Theory and Practice in 2005)

In 2008 The Green Paper on Territorial Cohesion was issued by the Commission of the European Communities (CEC) as an attempt to achieve a shared and consensual definition of territorial cohesion and, more importantly, the implications for policy. It is suggested there that the concept should be associated with a more balanced distribution and accessibility of cities and towns across Europe as well as with improved territorial cooperation. All these claims should, in particular, be very sensitive regarding the context and specificities of different types of territories, regions and places (CEC 2008). Although hundreds of contributions from national governments, local and regional authorities, EU institutions, economic and social partners, civil society organisations, academics and citizens were submitted in response to the open consultation process, a synthesised report including a more narrow definition has not yet been released. As touched upon above, it seems that this task appears to have been left to the scientific and policy advisory communities that work under the ESPON programme.

On the other hand, the normative concept of territorial cohesion has permeated some key informal strategic policy documents at the transnational scale in the meantime. One example is the Territorial Agenda (cf. TA 2007), or, as it is named in the subtitle, Towards a more competitive and sustainable Europe of diverse regions, which has been adopted by the ministers of the Member States of the European Union responsible for spatial planning and development. It declares the normative notion of territorial cohesion the most prominent task of territorial policies. A central motivation appears to lie in better exploiting existing territorial diversity within the EU.

The recent Territorial Agenda, TA 2020, starting with 2011, has been adapted to the Europe 2020 strategy. The latter was launched by the European Commission in March 2010 and approved by the Heads of States and Governments of EU countries in June 2010. It can be seen as the general road map of EU policy targets within this decade in regards to central policy fields (employment, energy, education and innovation), central for the future alignment of EU Cohesion policies between 2014 and 2020 (cf. TA 2020). Consequently, the TA 2020 takes up the policy triad proposed by the Europe 2020 strategy, namely: smart, sustainable and inclusive growth, and rephrases it in its subtitle Towards an Inclusive, Smart and Sustainable Europe of Diverse Regions. It appears that in doing so, the authors of the TA 2020, as the ministers responsible for spatial planning and development 
of the Member States of the European Union, are exploiting a window of opportunity as territorial cohesion has become a shared competence of the EU and its Member States, due to its integration in the Lisbon Treaty. That is, in the TA 2020, this specific group claims in a very pronounced way the incorporation of the territorial dimension to a much larger extent as an integral part of economic and social cohesion policy undertaken by the EU (cf. Schmitt 2011:4).

The TA 2020 also emphasises that the diversity of territories is a potential for development. For this, a place-based approach to policymaking, as elucidated in the Barca-Report (2009), is central to the inclusion of evidence-informed policymaking and integrated functional area development. In this light, the place-based approach to policymaking and delivery is considered to be particularly aligned with principles of territorial cohesion, resting as it does on horizontal coordination, evidence-based policymaking, and integrated functional area development. Territorial cohesion is, however, not the same as spatial development policy in general, but, instead, is more specific:

"Territorial cohesion is a twofold concept. It aims to strengthen endogenous potential in territories so as to overcome imbalances between territories. On the one hand territorial cohesion is linked to ideas of equity and balance and on the other is concerned with increasing territorial capital and development potential. Place-based comparative advantages or territorial capital are important assets for endogenous development. Thus, to achieve a high level of global competitiveness, effective utilization of territorial capital is centrally connected to the aim of territorial cohesion." (Schön 2005:393)

However, territorial cohesion remains a vague concept, perhaps intentionally and necessarily, since a robust definition would render it politically unusable (Davoudi 2005; Vanolo 2010). According to some researchers, territorial cohesion and competitiveness have, become depoliticized high-politics and the internal contradictions have been naturalized through the harmonization of contradictions (Vanolo 2010). Furthermore, territorial cohesion can be understood in different ways and overlap with other established notions, such as socio-economic convergence, economic competitiveness, spatial planning, or policy coordination (Evers 2012). Consequently, there is a tension within the concept between, on the one hand, the socio-economic balance between regions and territorial competitiveness on the other, which becomes inevitably an issue for spatial planning and policy coordination. Here, as stated before, in particular the ESPON Programme has become a nucleus of developing common mind-sets on what territorial cohesion is (or can be) and what it means in terms of policy implementation and coordination by providing scientifically robust knowledge in terms of territorial analysis, but also regarding the applicability and identification of policy options to better address the territorial dimension.

A concept, such as territorial cohesion, or related ones, such as territorial capital, is an abstract idea and as such continuously created and re-created by various actors in various contexts. Concepts used within the EU and in the field of territorial development are as a matter of fact normative and tend to seep into the academic language and become theorised (cf. the discussion by Lovering 1999) while other concepts (e.g. the central-place theory by Christaller) follow the opposite journey. This tension between research and policy is an integral part of the ESPON Programme, which is a difficult tightrope walk between applied research and policy consultancy. Nonetheless, within the so-called targeted analysis projects, policymaking and research are brought together, forming an interesting quality for the co-production of knowledge in regards to territorial cohesion and related issues. 


\section{Territorial approaches to regional potential and challenges}

The ESPON 2013 Programme aims to "inspire policy making by territorial evidence". In line with this claim, the specific objective of the ESPON DeTeC project has been, as mentioned above, to develop practical guidance on how local and regional stakeholders, practitioners and policymakers, can use ESPON knowledge for detecting territorial potentials and challenges. In the project, five territorial approaches have been identified and developed in order to link ESPON results with local and regional issues. Territorial approaches to regional development were specifically discussed in the report 'Regional Use of ESPON Knowledge: Inspiration for Researchers and Practitioners involved in Regional Territorial Analysis and Policy Development' from 2010. It was emphasised that regional territorial evidence and analysis can be used to "describe ways to approach the larger territory and intend to provide corresponding examples of policy and research questions, research methods and research outputs" (ESPON 2010:11). Based on this report and a thorough review of various ESPON projects, five territorial approaches for detecting the territorial potential and challenges of a region have been identified (for more information on the methodology of the project see ESPON DeTeC 2014).

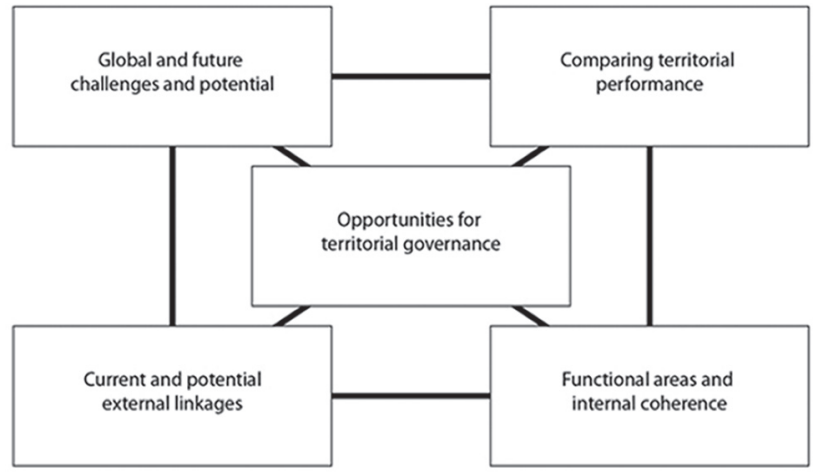

Figure 1. The territorial approaches of ESPON DeTeC

A territorial approach is an essentially geographical perspective on local and regional development. The territorial approaches in the $\mathrm{DeTeC}$ project have been developed against the background of the concept of territorial cohesion but also in relation to, first: key geographical processes; exogenous and endogenous forces of globalisation and regionalisation, second: regarding key geographical conceptualisations; in relation to relational and territorial approaches to regions, spaces of places and spaces of flows, and third: a particular focus on opportunities for territorial governance and how a European perspective can contribute to local and regional policy-making (see Figure 1). The territorial approaches contain and lead towards different methods of analysis used in different ESPON projects and are in this respect of pragmatic and practice-oriented character, all presented in an interactive e-handbook. The handbook provides, through five territorial approaches, the practical guidance for strategic local and regional policy-making. The five territorial approaches presented below have been designed to focus attention on important issues and to encourage new perspectives in local and regional development processes, and also to support local and regional stakeholders (i.e. practitioners and policymakers) working with long-term strategic development and spatial planning, e.g. to support the design and evaluation of regional development plans and programmes. 
To operationalize the territorial approaches, five concepts have been identified within the ESPON programme as particularly useful. These concepts are simultaneously both policy-oriented and of more analytical character. The first concept is territorial capital, which refers to a region's territorial assets for endogenous development, and the second is metropolisation, indicating a specific form of urban restructuring, growth and form. The third concept is polycentricity, indicating that a spatial entity, e.g. a functional urban area, consists of multiple centres, and the fourth concept is spatial integration indicating the existence of interactions between areas separated by a boundary. The fifth and final concept is territorial governance which refers to the coordination, formulation and implementation of public policies, programmes and projects for the development of a place or territory.

\section{Addressing exogenous challenges and endogenous potential}

The process of globalization and regionalisation offers both challenges and opportunities for the different regions in Europe. The development potential and challenges are, however, geographically uneven with an increased concentration of activities to certain areas, meaning that the regional context and local resources become increasingly important. The enlargement of the EU territory also offers potential for new markets and resources but also unprecedented challenges for attaining smart, sustainable and inclusive growth as outlined in the Europe 2020 Strategy. The territorial approaches have been firstly rooted in the tension between exogenous forces and endogenous growth potential, which is directly reflected in the first two territorial approaches.

The first territorial approach, global and future challenges and potential of a region, is based on the idea that the territorial development of a region is increasingly influenced by external processes and macro challenges such as globalization and regionalisation, demographic and climate change. It is therefore important to identify, monitor and analyse global and regional changes that directly or indirectly influence and affect the territorial development of a region. The approach points to the different external and exogenous forces that impose themselves on the region, but also highlights the importance of developing spatial scenarios and regional forecasts to approximate the future situation of a region. This approach also highlights the importance of recognising and understanding policy concepts, such as territorial cohesion, as well as what these concepts mean in terms of regional development in the region at hand. Finally, it seems to be central to assess and anticipate the territorial impacts of international and national directives and policies. To that end, the ESPON Programme offers different methods of analysis with specific potential for analysing these issues, e.g. spatial scenarios (ESPON SS-LR 2010), territorial impact assessment (ESPON EATIA 2012) and territorial performance monitoring (ESPON TPM 2013).

A key issue in detecting global and future challenges and potential is to analyse the territorial capital of a region. Territorial capital refers to a region's territorial assets for development and is related to the internal and endogenous potential of a region (Davoudi et al, 2008). It is a concept used, for example, in the ESPON SS-LR project, but also by other policy research institutes. The OECD, for instance, defines it as the "stock of assets which form the basis for endogenous development in each city and region, as well as (...) the institutions, modes of decision-making and professional skills to make best use of those assets" (OECD 2001). There are various forms of territorial capital; infrastructure and material structure of a region; cognitive, intellectual and human capital, cultural and environmental resources of a region, and the social and civil capital (cf. ESPON SS-LR 2010: 
12-13). The concept thus takes into account the tangible and intangible aspect, as well as public and private assets (Camagni 2008).

The second territorial approach, detecting and comparing territorial performance of a region, is based on the idea that every region is unique and supposedly strives to improve its performance in a European perspective. The approach emphasises that to detect and expose the territorial characteristics and compare the region's performance it is essential to contextualise the region in relation to other spatial entities. To compare the territorial performance of a region, it is important to identify the type of region and other comparable regions for which the typologies developed within the ESPON Programme might be helpful (ESPON 2011). The performance of a region relates to its comparative advantage for agglomeration economies and endogenous growth potential. The innovative ESPON methods of analysis that have specific potential for analysing these questions, are, for example, understanding differential growth dynamics (ESPON SURE 2010) and urban growth modelling (ESPON CAEE 2010).

A key (ESPON) policy and research concept that can be useful in this context is that of metropolisation. It is a concept referring to processes of "increasing concentration of economic development potential of the research-intensive industries and knowledge-intensive services on metropolitan regions and urban agglomerations" (Krätke 2007). Thus, it is also closely connected to urban growth and agglomeration economies: urbanization economies and localization economies. Agglomeration economics is about how concentration of economic activities leads to positive external effects in terms of, for example, "technological spillovers, an increasingly skilled labour pool, and firm-supplier networks" both within industries (localization economies) and across industries and sectors (urbanization economies) (ESPON CAEE 2010:5).

In the ESPON POLYCE project the above concept was used to indicate a specific form of urban restructuring, urban growth and polycentricism (ESPON POLYCE 2012). In the project it was emphasized that metropolisation is a process defined by a number of interconnected aspects and processes of spatial concentration of (new knowledge intensive) economic activities, command and control functions and human capital (cf. Bourdeau-Lepage \& Huriot 2002).

“... metropolisation is not similar throughout all cities, of course. Economic and demographic growth in the agglomeration, economic restructuring and polycentric features on different scales appear way differently in different cities. Also, the process of metropolisation reaches beyond city borders, producing a specific social, economic and spatial outcome, which depends on local influencing factors. Through these place-related influencing factors, metropolisation leads to specific local metropolitan characteristics. It produces metropolitan profiles, which differ throughout European cities, although metropolisation is a general trend." (ESPON POLYCE 2012:7)

Metropolisation is thus a process of uneven spatial development, which is not only related to urban agglomerations, but extends beyond traditional borders, forming new types of urban city-regions.

\section{Conceptualising regional territories within relational spaces}

Cities and towns, regions, or any other sort of places are part of various networks that extend far beyond the traditional territorial boarders. Castells (1996) has termed this the 'spaces of flows' and 'spaces of places'. In this vein, one can argue that a region is not only affected by its immediate surrounding areas, but increasingly by other places around the world. This, of course, has crucial 
implications for both regional analysis and regional policies. There is a tension between bounded regional territories and relational flows and regional formations, which is recognised in the third and the fourth territorial approach.

The third territorial approach, detecting the functional areas and internal coherence of a region, is based on the idea that every region is internally diverse and that each administrative region is part of multiple functional areas. It emphasises the questions such as: What are the functional areas and what is the wider territory of the region at hand? How is the region structured in view of internal coherence and spatial integration? As a matter of fact, a functional area can extend beyond the administrative territory of a region. A region can also be a part of multiple functional areas. Furthermore, the functional area (and administrative territory) can be more or less coherent. There is a plethora of different regions and new regional formations are emerging, based on different forms of criteria at different scales. A number of ESPON projects have focused on demarcating functional and morphological urban areas (see for example ESPON M4D 2014). A functional urban area can consist of one or more morphological urban areas, but is not necessarily limited by administrative boundaries. Although regions are most often conceived in terms of core and periphery, the spatial structure of many regions is more complex, and can often more accurately be described in terms of their morphological and functional-relational polycentricity.

Polycentrism has become one of the most central normative strategies to achieve territorial cohesion in Europe. Polycentricity refers, however, to an empirical spatial pattern and can be analysed and detected at different (European) scales from the intra-urban (i.e. London and Paris) and inter-urban (e.g. Randstad) (Klosterman \& Musterd 2001), while polycentrism is a normative and prescriptive political concept (Vandermotten et al. 2008). Polycentricity is often perceived as "a self-explanatory concept, characterising something that is opposite to monocentric on the one hand and dispersal and sprawl on the other" (ESPON 1.1.1 2005:51), but it should not be confused with territorial networking at multiple scales.

"Polycentric urban system is a functionally integrated socio-spatial entity that consists

of multiple urban nodes that may differ in size yet all play important role in the system, are

linked through intensive reciprocal and multidirectional relations with further development

influenced by governance strategies that recognize, consider and support future enhancement

of mutual interests, complementarities, synergies and potential for collaboration." (ESPON

POLYCE 2012:21)

The emphasis on polycentricity and different types of urban networks and co-operation beyond traditional municipal and regional borders extends further in the fourth territorial approach, detecting current and potential external linkages of a region. This territorial approach is based on the idea of spaces of flows and networks, and the increased importance of external flows and relational networks spans across regional, national and international borders, this being, for instance, expressed through international relations and cross-border interactions. The connectivity and accessibility of a region depends on various networks and flows; transport linkages, ICT, business networks, but also on the spatial position of the region at hand in the European urban and regional system. The concept of spatial integration is essential in this context, since it indicates the existence and strength of interactions between areas separated by a boundary.

In the Study Programme on European Spatial Planning, which followed the key policy options conveyed by the European Spatial Development Perspective (ESDP), spatial integration was defined as "a system of links (flux, similarities, proximity, territoriality, connectivity, ...) between territories which is the emerging result of concrete social, economic, and cultural relationships, but this system 
is also a structure which influences and sometimes determines the further development of social, economic and cultural links" (de Boe et al. 1999:30). The concept of spatial integration includes functional integration and cross-border integration, but also relates to issues of polycentricity and urban systems (Vasanen 2013:411), as well as to territorial governance, since:

"These interactions are not limited to the economic sphere, but concern also other flows or transactions (cultural, political relations, migration, etc.). The existence of interactions does not necessarily mean that the territories converge. Some relationships can be highly asymmetric and be fed by strong differentials. It is therefore necessary to complete the analysis by considering the possible convergence of the territories." (ESPON METROBORDER 2010:37).

In line with this, it is possible to systematically approach spatial integration in a dynamic way with regard to different aspects, such as density, transport networks, urban networks, flows, territorial homogeneity. Assessing polycentric development (ESPON POLYCE 2012), and assessing functional integration (ESPON METROBORDER 2010), are two innovative ESPON methodologies for analysing the internal and external linkages of a region. The project ESPON METROBORDER analysed functional cross-border integration in terms of interactions (flow analysis and barrier effects) and convergence (analysis of homogeneity and discontinuities) between territories (2010:37). The method of cross-border institutional mapping, which was also developed within the ESPON METROBORDER, is also applicable in this relation. Further, this also relates to the fifth territorial approach, which will be discussed in the following section.

\section{On governance and the fluidity of scales and places}

As a consequence of the above discussed framework of regional territories being embedded within relational spaces, regional policy needs to be context sensitive and place-based, but also oriented and adapted to larger territories. Thus, regions do not develop in isolation, but are increasingly dependent upon and integrated with the surrounding world. An important starting point within the ESPON DeTeC project has been the relational conceptualisation of regions and scales. Both regions and scales are social constructs "structured and institutionalized in complex ways in de/re-territorializing practices and discourses that may be partly concrete, powerful and bounded, but also partly unbounded, vague or invisible" (Paasi 2004:542). A region is thus not only a larger (scale) place, but a region is (just as a place) both global and local, open and fluid and not a fixed territorial entity in between national scale and the local scale (cf. Massey 2004).

An overarching challenge is, of course, how to govern open and fluid regions and their specific (eventually) changing scales, dependent on the particular issue at hand. The fifth territorial approach, opportunity for territorial governance of a region, is based on the idea that the territorial organisation, institutional arrangements and practices are crucial for regional development and territorial cohesion policy. Detecting opportunities for territorial governance is about exploring different forms of institutional arrangements and organizational practices that can help turning regional challenges into regional potential. Territorial governance, as defined below, might offer a useful framework in this respect, especially since it includes issues such as policy integration, collaborative planning, cross-border cooperation, and institutional capacity. A territorial perspective on governance refers to "the process of organization and co-ordination of actors to develop territorial capital in a nondestructive way in order to improve territorial cohesion at different levels" (Davoudi et al. 2008:50). The ESPON TANGO project provides a more elaborate definition of territorial governance as "the 
formulation and implementation of public policies, programmes and projects for the development of a place/territory by 1) co-ordinating actions of actors and institutions, 2) integrating policy sectors, 3) mobilising stakeholder participation, 4) being adaptive to changing contexts, 5) realising placebased/territorial specificities and impacts" (ESPON TANGO 2012).

The territorial approach of detecting opportunities for territorial governance is thus of a more practice-oriented character than the four other approaches, which are rather more analytical. It comprises the tension of the interactions between policymaking and research and is simultaneously surrounded by other tensions reflected within and between the other approaches (see Figure 1). To summarize, the first and second territorial approach are related to issues of territorial cohesion, and the tensions between social inclusion and economic competitiveness. Both the first and the fourth approaches are about different external forces and relations affecting the regions, related to the environment, demography and technology, and to processes of globalization and regionalization, but also regarding international and national policies that might affect the region. These approaches highlight that each region is situated within a larger context, while the second and third territorial approaches are more related to the internal conditions of the region and endogenous growth potential, and the competitive advantages of the region at hand. The third and fourth territorial approaches also emphasise different aspects of a territorial and relational perspective, namely consider them as integral elements of the spaces of flows and spaces of places. The fifth approach, however, is about the capacity to organise, formulate and negotiate policies, programmes and projects in order to meet some of the challenges mentioned above, and, if successfully applied, should help to turn challenges into potential based on the place-based and territorial specificities in the region at hand.

\section{Conclusion}

The territorial approaches developed within the ESPON DeTeC project can give practical guidance for strategic local and regional policy making by focusing attention towards important policy issues for territorial cohesion and by opening up new perspectives in local and regional development. The approaches have been developed within a European perspective and with a focus on the notion of territorial cohesion, and thus provide help to understand the position of a region in a larger context, which is crucial for developing new regional strategies and policies and for capitalising on territorial potentials. This larger context does not only include Europe as such, but also relations with neighbouring regions, macro-regions, and the impacts of global issues. But the territorial approaches simultaneously also recognise the different tensions within the normative concept of territorial cohesion, between exogenous challenges and endogenous potential, as well as between regional territories and relational spaces.

Since the ESPON Programme is a nucleus for the knowledge-based interpretation (by developing various indicators, thematic maps etc.) of the normative concept of territorial cohesion through the several applied research projects and targeted analysis, the territorial approaches being presented here address the issue of how to use ESPON knowledge at local and regional levels in view of its application. Quantifiable indicators are a fundamental element of most of applied research and targeted analysis projects within ESPON. Even if a general aim of ESPON is to use and produce Europe-wide data to assess various territorial dynamics in cities and regions, the indicators are also one of the key challenges in both analysing and using ESPON knowledge at the local and regional levels, meant, finally, to identify and design policies, programmes and projects in view of applying 
the concept of territorial cohesion. In this vein, the five territorial approaches, outlined above, are a way of confronting the territorial challenges at hand, which are often expressed through vague and general indicators at aggregated spatial scales, by focusing on more general and generic tools in regards to targeted analysis, scale and timing of specific indicators, as well as identification of policy options. Therefore we argue that the five territorial approaches can help to make the extensive and diverse ESPON knowledge more tangible and finally applicable for local and regional stakeholders working in different territorial contexts across Europe by providing some hands-on support for place-based policy making.

It is finally worthwhile to recall Aristotle's separation between potentiality and actuality to understand what a potential might be. A piece of bronze is potentially a statue, but it also has the potentiality of becoming a hammer or kettle, but the metal does not have the potentiality to become a wooden house, or food, or so forth. Potentiality thus refers to initial conditions of the matter, but it is not the same thing as possibility: "to say that $\mathrm{x}$ is potentially $\mathrm{F}$ is to say that $\mathrm{x}$ already has actual features in virtue of which it might be made to be F by the imposition of a F form upon it" (Shields 2013). Hence, in conclusion, we argue that the potential of a region refers to the latent abilities and capacities of the region, and what a potential is needs to be defined based on its inherent features. A potential cannot be defined a priori, but place-based policies need to be derived from and within a given place/region, and, simultaneously, harmonized across space and various scales. In this, a region is not a fixed material entity, but a social construction continuously changing and evolving. A key question is thus what inherent capacities and potentials a region has to acquire and develop, as well as how it can regain other capacities to confront and adapt to new challenges. This brings us back to the key addressees of the above discussed five territorial approaches, who are the local and regional stakeholders (i.e. practitioners and policymakers) working with territorial analysis and policy design and formulation.

\section{References}

Barca F., 2009, An Agenda for a Reformed Cohesion Policy: A place-based approach to meeting European Union challenges and expectations (Independent Report prepared at the request of Danuta Hübner, Commissioner for Regional Policy). http://ec.europa.eu/regional_policy/archive/ policy/future/pdf/report_barca_v0306.pdf

Bourdeau-Lepage L., \& Huriot J.-M., 2002, Metropolisation in Warsaw: Economic Change and Urban Growth. Canadian Journal of Regional Science, 25(3), pp. 423-446.

Camagni R., 2008, Towards a Concept of Territorial Capital. [in:] R. Capello, R. Camagni, B Chizzolini \& U. Fratesi (eds.) Modelling Regional Scenarios for the Enlarged Europe. Springer, Berlin, pp. 29-45.

Castells M., 1996, The Rise of the Network Society (Vol. 1). Malden, Mass.: Blackwell, 556 pp.

CEC, 1999, European Spatial Development Perspective: Towards Balanced and Sustainable Development of the Territory of the European Union (Agreed at the Informal Council of Ministers responsible for Spatial Planning in Potsdam). European Commission. http://ec.europa. eu/regional_policy/sources/docoffic/official/reports/pdf/sum_en.pdf

CEC, 2008, Green Paper on Territorial Cohesion: Turning territorial diversity into strength. Brussels: Commission of the European Communities. http://eur-lex.europa.eu/LexUriServ/LexUriServ.do?uri=COM:2008:0616:FIN:EN:PD 
Davoudi S., 2005, Understanding territorial cohesion. Planning, Practice \& Research, 20(4), pp. 433-441.

Davoudi S., Evans N., Governa F., \& Santangelo M., 2008, Territorial Governance in the Making: Approaches, Methodologies, Practices. Boletín de la Asociación de Geógrafos Espańoles, 46, pp. 33-52.

De Boe P., Grasland C., Healy A., Hanquet T., \& Robert D., 1999, Spatial Integration (Final Report). http://www.mcrit.com/spesp/SPESP_REPORT/spatial_integration.pdf

Duehr S, Colomb C. \& Nadin V., 2010, European Spatial Planning and Territorial Cooperation. Routledge: London, New York, 480 pp.

ESPON 2010, Regional Use of ESPON Knowledge: Inspiration for Researchers and Practioners involved in Regional Territorial Analysis and Policy Development (Working Paper from the internal ESPON Seminar on 3-4 December 2009 in Malmö). http://www.espon.eu/export/sites/ default/Documents/Publications/SeminarsReports/Malmoe_Seminar_Report.pdf

ESPON 2011, Regional Typologies, data and metadata. http://www.espon. eu/main/Menu_ToolsandMaps/ESPONTypologies/

ESPON 1.1.1., 2005, Urban areas as nodes in a polycentric development (Final Report). http://www. espon.eu/export/sites/default/Documents/Projects/ESPON2006Projects/ThematicProjects/Polycentricity/fr-1.1.1_revised-full.pdf

ESPON 2.3.2., 2007, Governance of Territorial and Urban Policies from EU to Local Level (Final Report). http://www.espon.eu/export/sites/default/Documents/Projects/ESPON2006Projects/ PolicyImpactProjects/Governance/fr-2.3.2_final_feb2007.pdf

ESPON CAEE, 2010, The case for agglomeration economies in Europe (Appendix C1: Investigating Agglomeration Economies in a panel of European Cities and Regions). http://www. espon.eu/export/sites/default/Documents/Projects/TargetedAnalyses/CAEE/CAEE_Investigating_Agglomeration_Economies_Appendix_C1.pdf

ESPON EATIA, 2012, ESPON and Territorial Impact Assessment (Final Report). http://www. espon.eu/export/sites/default/Documents/Projects/TargetedAnalyses/EATIA/FinalReportEATIA28June2012Afinal.pdf

ESPON M4D, 2014, ESPON 2013 Database Dictionary of Spatial Units (Draft). http://database.espon. $\mathrm{eu} / \mathrm{db} 2 /$ jsf/DicoSpatialUnits/DicoSpatialUnits_onehtml/index.html

ESPON METROBORDER, 2010, Cross-border Polycentric Metropolitan Regions (Final Report). http://www.espon.eu/export/sites/default/Documents/Projects/TargetedAnalyses/METROBORDER/METROBORDER_-_Final_Report_-_29_DEC_2010.pdf

ESPON POLYCE, 2012, Metropolisation and Polycentric Development in Central Europe (Final Report). http://www.espon.eu/export/sites/default/Documents/Projects/TargetedAnalyses/ POLYCE/FR/POLYCE_FINAL_MAINREPORT.pdf

ESPON SS-LR, 2010, Spatial Perspectives at Nuts-3 Level (Final Report). http://www.espon.eu/export/ sites/default/Documents/Projects/TargetedAnalyses/SS_LR/SS-LR_final_report_and_annexes. pdf

ESPON SURE, 2010, Structured empirical analysis for convergence regions: identifying success factors for consolidated growth (Final Report). http://www.espon.eu/export/sites/default/Documents/Projects/TargetedAnalyses/SURE/SURE_FinalReport_and_annexes.pdf

ESPON TANGO, 2012, Territorial Approaches for New Governance (Interim Report). Retrieved from http://www.espon.eu/export/sites/default/Documents/Projects/AppliedResearch/TANGO/ ESPON_TANGO_Interim_Report_final.pdf 
ESPON TPM, 2013, Territorial Performance Monitoring (Final Report). Retrieved from http:// www.espon.eu/export/sites/default/Documents/Projects/TargetedAnalyses/TPM/FinalReport/ ESPON_TPM_FinalReport.pdf

ESPON DeTeC, 2014, Detecting Territorial Potentials and Challenges (Final Report).

Evers D., 2012, A Solution in Search of a Problem: A "Garbage Can" Approach to the Politics of Territorial Cohesion. European Journal of Spatial Development, February (45). http://www. nordregio.se/Global/EJSD/Refereed\%20articles/refereed45.pdf

Kloosterman R. C., Musterd S., 2001, The Polycentric Urban Region: Towards a Research Agenda. Urban Studies, 38(4), pp. 623-633.

Krätke S., 2007, Metropolisation of the European economic territory as a consequence of increasing specialisation of urban agglomerations in the knowledge economy. European Planning Studies, 15(1), pp. 1-27.

Lovering J., 1999, Theory led by Policy: The Inadequacies of the 'New Regionalism' (Illustrated from the Case of Wales). International Journal of Urban and Regional Research, 23(2), pp. 379-395.

Massey, D. (2004). For Space. London: SAGE, 222 pp.

OECD, 2001, OECD Territorial Outlook. Organisation for Economic Co-operation and Development, 279 pp.

Paasi A., 2004, Place and region: looking through the prism of scale. Progress in Human Geography, 28(4), pp. 536-546.

Planning Theory and Practice (2005). Interface on: Territorial cohesion 6(3), pp. 387-409.

Schön P., 2005, Territorial Cohesion in Europe? Planning Theory and Practice 6(3), pp. 389-400.

Schmitt P., 2011, The Territorial Agenda of the European Union 2020 - A turning point in striving for Territorial Cohesion? Nordregio News 1/2011, pp 3-8.

Scott J. W., 2009, Europe of Regions. [in:] R. Kitchin \& N. Thrift (eds.) International Encyclopedia of Human Geography, Elsevier, Oxford, pp. 649-657.

Shields C., 2013, Aristotle. [in:] E. N. Zalta (ed.), The Stanford Encyclopedia of Philosophy (Winter 2013 Edition.). http://plato.stanford.edu/archives/win2013/entries/aristotle/

SPESP, 2000, Study Programme on European Spatial Planning 1998-1999. http://www.mcrit. $\mathrm{com} / \mathrm{SPESP} /$

TA, 2007, Territorial Agenda of the European Union: Towards a More Competitive and Sustainable Europe of Diverse Regions (Agreed on the occasion of the Informal Ministerial Meeting on Urban Development and Territorial Cohesion in Leipzig on 24 / 25 May 2007). http://www. eu-territorial-agenda.eu/Reference\%20Documents/Territorial-Agenda-of-the-European-UnionAgreed-on-25-May-2007.pdf

TA 2020, 2011, Territorial Agenda of the European Union 2020: Towards an Inclusive, Smart and Sustainable Europe of Diverse Regions (agreed at the Informal Ministerial Meeting of Ministers responsible for Spatial Planning and Territorial Development on 19th May 2011 Gödöllö , Hungary).

Vandermotten C., Halbert L., Roelandts M., Cornut P., 2008, European Planning and the Polycentric Consensus: Wishful Thinking? Regional Studies, 42(8), pp. 1205-1217.

Vanolo A., 2010, European spatial planning between competitiveness and territorial cohesion: Shadows of neo-liberalism. European Planning Studies, 18(8), pp. 1301-1315.

Vasanen A., 2013, Spatial Integration and Functional Balance in Polycentric Urban Systems: A MultiScalar Approach. Tijdschrift voor economische en sociale geografie, 104(4), pp. 410-425. 
http://rcin.org.pl 